\title{
Foraging habits and behaviour of moose calves in virgin forests
}

\author{
Simona KOSSAK
}

\begin{abstract}
Kossak S. 1992. Foraging habits and behaviour of moose calves in virgin forests. Acta theriol. 37: $51-61$.

Foraging habits of two hand-reared moose Alces alces (Linnaeus, 1758) calves were observed from 22 June to 20 July, 1990. The animals foraged freely while wandering in the Białowieża National Park, Poland. The intensity of foraging was measured by counting the contacts (i.e. bites followed by swallowing of a plant part). Altogether, 4,408 contacts with plants of 42 species were recorded. During the month of observations the number of contacts and the number of species of plants eaten by moose did not increase significantly. There was a positive correlation between the number of contacts and the number of species of plants eaten by moose during a day. Some random choice of forage by the calves, statistically significant (but decreasing with time) quantitative differences in the food preferences between the two moose, behavioural data about strong bonds between moose calves and their mother, and comparison with the development of foraging habits in roe deer fawns formed a basis for the hypothesis that the mimicring of the mother's behaviour is an important mechanism in the development of foraging habits in moose calves.
\end{abstract}

Forest Research Institute, Department of Nature Protection, 17-230 Białowieża, Poland

Key words: Alces alces, foraging habits, behaviour, virgin forest, Białowieża National Park, Poland

\section{Introduction}

Moose Alces alces (Linnaeus, 1758) are adapted to feeding on both hard ligneous and soft green vegetation. In comparison with red deer, fallow deer, and particularly with roe deer, moose are clearly less fastidious about the choice of species and parts of plants. Among others it is a result of the fact that the rumen of moose has the large number of villi, it is characterized by a high index of fermentation and quick digestion process (Hofmann 1978).

The aim of this study was to determine the choice of forage and the development of foraging behaviour in moose calves, which were allowed to wander freely in the biotopes preferred by moose in pristine forests.

It was assumed that the low selectivity in the choice of forage observed in adult moose would also be found in the calves' foraging. The foraging behaviour of moose calves was supposed to be much different than that observed in the roe deer fawns, the most fastidious cervids in terms of food choice. 


\section{Material and methods}

The studies were conducted in the strict reservation of the Białowieża National Park (BNP) $\left(23^{\circ} 51^{\prime} 15^{\prime \prime}-23^{\circ} 53^{\prime} 49^{\prime \prime} \mathrm{E}, 52^{\circ} 42^{\prime} 35^{\prime \prime}-52^{\circ} 48^{\prime} 06^{\prime \prime} \mathrm{N}\right)$ in Poland (Fig. 1). The most important feature of the BNP $(4,643 \mathrm{ha})$ is the natural, pristine character of its forests.

A free-living population of moose inhabits the Białowieża Primeval Forest.

Foraging by moose was observed in the south-eastern part of the Park, which contains the ecosystems preferred by moose (Figs 1 and 2). The calves wandered in the rich fresh and humid deciduous forests. In many places, water stagnated in ponds and puddles during spring. The area of the Orł6wka stream (forest compartments no. 344D and 345C) was covered with bog alderwood and ash-alderwood (with Alnus glutinosa and Fraxinus excelsior) and flooded in many places. The choice of the study area was determined by the habitat preferences of female moose leading calves (according to Leptich and Gilbert 1989).
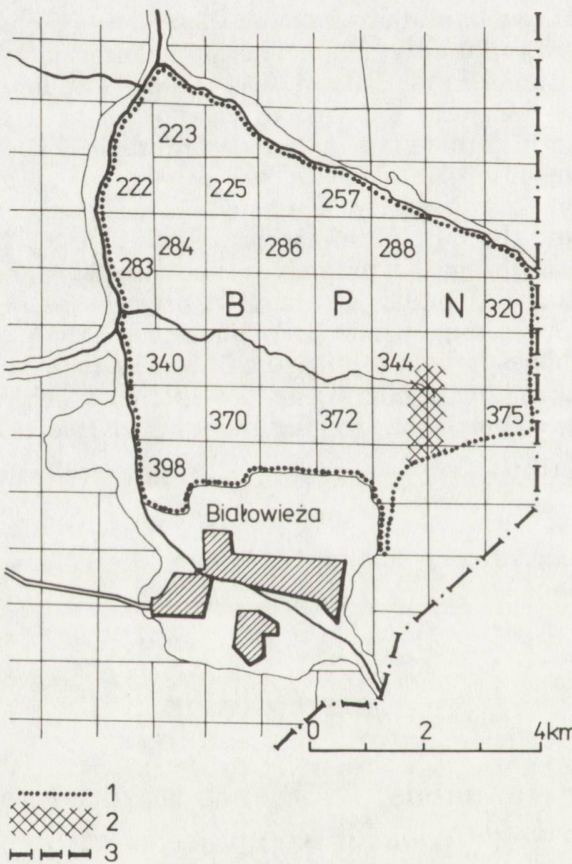

Fig. 1. Map of the study area. 1 - border of the strict reservation of the Białowieża National Park; 2 - the area penetrated during the observation period; 3 - state border of Poland. Numbers denote forest compartments.

Observation were conducted on two male moose calves (A and B) born by a wild female. The calves were born in early May 1990 in Morze (Białystok voivodship) and were brought to the zoological garden in Białystok when they were few days old. On May 18th, they were brought to the Białowieża Primeval Forest and placed in the 0.1-hectare pen, which contained trees and shrubs, and was adjacent to the strict reservation of the Białowieża National Park.

The calves were bottle-fed with powdered cow milk. The following of the calves was undertaken by the author when the calves accepted the author as their 'mother', which happened after about 2 weeks of their stay in the pen. The first wanderings were short; the calves lay after several minutes 
of walking because their physical development (particularly that of male B) was slow. Full physical ability was attained by the calves during their 5th week of life when they could tirelessly walk for about $3 \mathrm{~km}$. Such a distance was within the summer home range size of the female-calf group (from $18.1 \mathrm{~km}^{2}$, Dunn 1976; to $25.8 \mathrm{~km}^{2}$, Crossley and Gilbert 1983). The observations of foraging by calves began on June 22nd and ended on July 20th, 1990, when the moose began to eat commercial cattle food and nutrients.

The behaviour of moose was observed in the mornings from $0600-0700 \mathrm{~h}$, which is the time of the most intense foraging activity of moose (Leptich and Gilbert 1983; Renecker and Hudson 1989). After having drunk 1 liter of milk each, the calves followed the author to the National Park. I led them slowly northward, using about $100 \mathrm{~m}$ belt on both sides of the forest path. During the

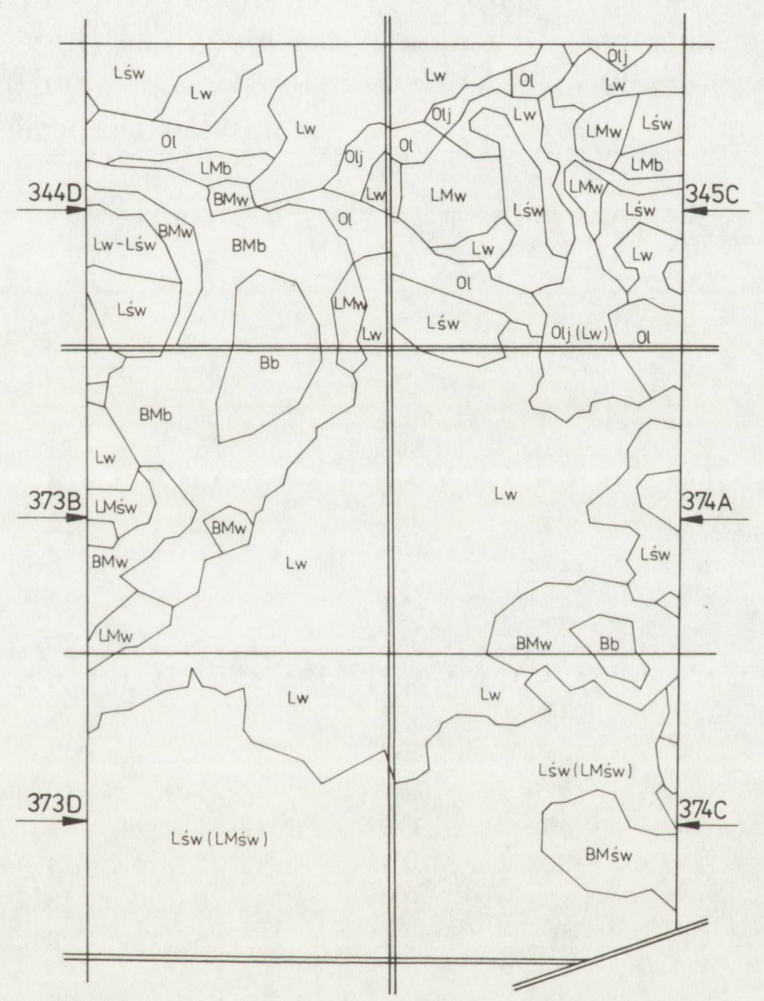

Fig. 2. Forest habitats in the area penetrated during the observation: Lw - fresh deciduous forest, $\mathrm{Lw}$ - humid deciduous forest, $\mathrm{Ol}$ - bog alderwood, $\mathrm{Olj}$ - ash-alderwood, $\mathrm{BMw}$ - humid mixed coniferous forest, $\mathrm{BMb}$ - bog mixed coniferous forest, $\mathrm{Bb}$ - bog pine forest. 373B, 344D - numbers of forest compartments.

wanderings, the moose walked, foraged, bathed, played, and lay. The excursions to the forest lasted $2-3$ hours. On some days, the calves were unwilling to go (especially during the hot weather or in days with intense activity of mosquitos), and then the observations were not conducted.

Foraging by moose was expressed in contacts. A contact was a bite of a plant part. The number of contacts and the number of species of consumed plants were noted on the observation sheets for each moose. It was possible to observe two animals simulataneously, because they foraged close to each other and close to the author. Additionally, the information about drinking, eating dirt, defecation, playing, and social behaviour was noted. 
A total of 14 observation days was collected for each moose; 4,408 contacts with 42 species of plants were recorded for both individuals.

\section{Results}

The intensity of foraging by moose calves

During the succesive days of observations, the intensity of foraging (the number of contacts or the number of plant species taken per time unit) did not increase. However, there were differences in the intensity of foraging in various days (Table 1). There was a positive correlation between the number of contacts and the number of plant species eaten by moose in a given day (Fig. 3). No significant differences in the intensity of foraging between moose A and B were noted ( $t=$ $0.84, p>0.1$ for contacts, $t=1.08, p>0.1$ for number of species).

Table 1. Number of contacts and species of plants taken by two moose calves (A and B) in consecutive days of observations.

\begin{tabular}{|c|c|c|c|c|c|c|}
\hline \multirow{2}{*}{ Date } & \multicolumn{3}{|c|}{$\mathrm{N}$ contacts } & \multicolumn{3}{|c|}{$\mathrm{N}$ species } \\
\hline & A & B & Total & A & B & Total \\
\hline 22 June & 132 & 210 & 342 & 15 & 11 & 18 \\
\hline $23 \ll$ & 100 & 209 & 309 & 10 & 9 & 12 \\
\hline $24 \ll$ & 206 & 273 & 479 & 10 & 12 & 13 \\
\hline $25 \ll$ & 335 & 192 & 527 & 6 & 8 & 11 \\
\hline $26 \ll$ & 133 & 158 & 291 & 8 & 4 & 10 \\
\hline $27 \ll$ & 96 & 101 & 197 & 9 & 8 & 9 \\
\hline $28 \ll$ & 126 & 91 & 217 & 11 & 8 & 13 \\
\hline 02 July & 148 & 104 & 252 & 6 & 7 & 9 \\
\hline $05 \approx$ & 190 & 307 & 497 & 12 & 11 & 18 \\
\hline $06 \ll$ & 125 & 173 & 298 & 12 & 10 & 13 \\
\hline $11 \ll$ & 77 & 102 & 179 & 5 & 5 & 5 \\
\hline $15 \ll$ & 189 & 200 & 389 & 13 & 14 & 16 \\
\hline $19 \ll$ & 52 & 78 & 130 & 9 & 10 & 12 \\
\hline 20 “ & 140 & 161 & 301 & 9 & 9 & 12 \\
\hline Total & 2049 & 2358 & 4408 & 37 & 36 & 42 \\
\hline $\mathrm{n}$ days & 14 & 14 & 14 & 14 & 14 & 14 \\
\hline $\bar{x}$ & 146.3 & 168.4 & 314.8 & 9.6 & 9.0 & 12.2 \\
\hline $\mathrm{SD}$ & 66.8 & 67.0 & 117.2 & 2.7 & 2.6 & 3.4 \\
\hline CV & $45.7 \%$ & $39.8 \%$ & $37.2 \%$ & $28.5 \%$ & $28.5 \%$ & $28.0 \%$ \\
\hline
\end{tabular}

\section{Food preferences in moose calves}

During the observation period, the moose foraged on 42 species of plants, of which the following were taken most often: Lysimachia vulgaris (33\%), Rubus saxatilis $(21 \%)$, and Tilia cordata (19\%). The other 39 species constituted $27 \%$ of all contacts. 
Some species of plants were consumed significantly more often by one moose than by another (Table 2). Moose A preferred Lysimachia vulgaris, Athyrium filix-femina, Stellaria holostea, Impatiens noli-tangere, and Milium effusum. Moose B preferred: Rubus saxatilis, Asperula odorata, and Myosotis palustris. The following species of plants were taken with the similar intensity by both calves: Tilia cordata, Vaccinium myrtillus, Carpinus betulus, Juncus effusus, and Lychnis flos-cuculi.

Data presented in Table 2 show that the two calves foraged on the same species of plants. Nonetheless, the intensities of their foraging on various species were different. Test $G$ was used to check if the share of a particular species of plants in the total number of contacts changed with time. Only the first 4 days $(22-25$ June) and the last 4 days ( $11-20$ July) of observation were taken into con-

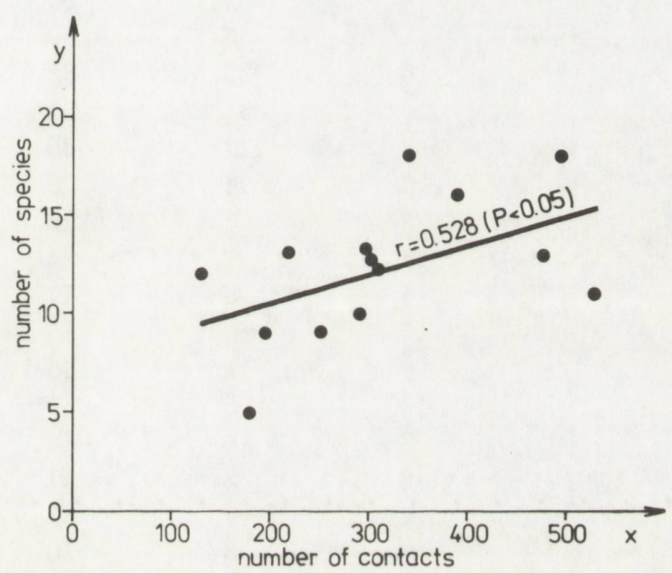

Fig. 3. Relationship between the number of plant species and the total number of contacts taken by moose calves in consecutive days of observation.

sideration (Table 3). Among the species listed in Table 3 and composing $92 \%$ of all contacts, only in the cases of Stellaria holostea and Juncus effusus the intensity of moose foraging did not significantly change with time. In the cases of Tilia cordata, Vaccinium myrtillus, and Carpinus betulus the intensity of foraging increased, whereas in the cases of Lysimachia vulgaris, Rubus saxatilis, Athyrium filix-femina, Impatiens noli-tangere, Lychnis flos-cuculi, and Sorbus aucuparia it decreased.

Because there were differences between the two calves in the intensity of foraging on some species of plants, the tendency to persist, to become more pronounced or to disappear was tested. Table 4 presents the results of $G$-test for 11 species of plants consumed by calves $\mathrm{A}$ and $\mathrm{B}$ in the beginning and in the end of the observation period. In the cases of Tilia cordata, Vaccinium myrtillus, Impatiens noli-tangere, Carpinus betulus, Juncus effusus, and Sorbus aucuparia 
Table 2. Contribution of various plant species to the total number of contacts taken by two moose calves (A and B) from 22 June to $20 \mathrm{July}$ ). ${ }^{* * *} p<0.001,{ }^{* *} p<0.01,{ }^{*} p<0.05$.

\begin{tabular}{|c|c|c|c|c|}
\hline \multirow{2}{*}{ Species } & \multicolumn{3}{|c|}{$\mathrm{N}$ contacts } & \multirow{2}{*}{$G$-test } \\
\hline & A & B & Total & \\
\hline Lysimachia vulgaris & 818 & 642 & 1460 & $21.27^{* * *} \mathrm{~A}$ \\
\hline Rubus saxatilis & 85 & 854 & 939 & $731.30 * * * \mathrm{~B}$ \\
\hline Tilia cordata & 405 & 422 & 827 & 0.35 \\
\hline Athyrium filix-femina & 248 & 25 & 273 & $211.29^{* * *} \mathrm{~A}$ \\
\hline Stellaria holostea & 85 & 41 & 126 & $15.69^{* * *} \mathrm{~A}$ \\
\hline Vaccinium myrtillus & 53 & 49 & 102 & 0.16 \\
\hline Impatiens noli-tangere & 68 & 24 & 92 & $21.93^{* * *} \mathrm{~A}$ \\
\hline Carpinus betulus & 42 & 28 & 70 & 2.82 \\
\hline Juncus effusus & 38 & 29 & 67 & 1.21 \\
\hline Lychnis flos-cuculi & 18 & 32 & 50 & $3.97^{*} \quad \mathrm{~B}$ \\
\hline Asperula odorata & 15 & 35 & 50 & $8.23^{* *} \mathrm{~B}$ \\
\hline Sorbus aucuparia & 10 & 22 & 32 & $4.61^{*} \quad \mathrm{~B}$ \\
\hline Agrostis stolonifera & 0 & 31 & 31 & $* * * \mathrm{~B}$ \\
\hline Myosotis palustris & 3 & 27 & 30 & $22.08^{* * *} \mathrm{~B}$ \\
\hline Mycelis muralis & 15 & 13 & 28 & 0.14 \\
\hline Milium effusum & 23 & 3 & 26 & $17.45^{* * *} \mathrm{~A}$ \\
\hline Acer platanoides & 17 & 7 & 24 & $4.30^{*}$ \\
\hline Vicia silvatica & 11 & 6 & 17 & \\
\hline Ranunculus repens & 10 & 5 & 15 & \\
\hline Betula pubescens & 4 & 11 & 15 & \\
\hline Quercus robur & 10 & 5 & 15 & \\
\hline Circaea alpina & 8 & 6 & 14 & \\
\hline Equisetum pratense & 9 & 2 & 11 & \\
\hline Fraxinus excelsior & 4 & 7 & 11 & \\
\hline Corylus avellana & 7 & 3 & 10 & \\
\hline Dentaria bulbifera & 7 & 2 & 9 & \\
\hline Rumex obtusifolius & 5 & 4 & 9 & \\
\hline Xerocomus sp. & 4 & 4 & 8 & \\
\hline Viola sp. & 3 & 4 & 7 & \\
\hline Dactylis glomerata & 5 & 1 & 6 & \\
\hline Oxalis acetosella & 3 & 5 & 6 & \\
\hline Iris pseudoacorus & 0 & 5 & 5 & \\
\hline Ranunculus lanuginosus & 4 & 0 & 4 & \\
\hline Eriphorum angustifolium & 4 & 0 & 4 & \\
\hline Chamaenerion angustifolium & 2 & 1 & 3 & \\
\hline Phragmites communis & 3 & 0 & 3 & \\
\hline Fragaria vesca & 0 & 3 & 3 & \\
\hline Ribes nigrum & 0 & 2 & 2 & \\
\hline Populus tremula & 1 & 0 & 1 & \\
\hline Dryopteris spinulosa & 1 & 0 & 1 & \\
\hline Vicia sp. & 1 & 0 & 1 & \\
\hline Salix caprea & 0 & 1 & 1 & \\
\hline Total & 2049 & 2359 & 4408 & \\
\hline
\end{tabular}


Table 3. Comparison of species composition of contacts taken by moose calves in two periods: $22-25$ June (1) and $11-20$ July (2). ${ }^{* * *} p<0.001,{ }^{* *} p<0.01$.

\begin{tabular}{|c|c|c|c|}
\hline \multirow{2}{*}{ Species } & \multicolumn{2}{|c|}{$\mathrm{N}$ contacts } & \multirow{2}{*}{ G-test } \\
\hline & 1 & 2 & \\
\hline Lysimachia vulgaris & 692 & 118 & $450.37^{* * *}$ \\
\hline Rubus saxatilis & 449 & 187 & $111.21^{* * *}$ \\
\hline Tilia cordata & 50 & 305 & $203.52^{* * *}$ \\
\hline Athyrium filix-femina & 135 & 68 & $22.53^{* * *}$ \\
\hline Stellaria holostea & 53 & 36 & 3.27 \\
\hline Vaccinium myrtillus & 7 & 95 & $90.39^{* * *}$ \\
\hline Impatiens noli-tangere & 41 & 12 & $16.77^{* * *}$ \\
\hline Carpinus betulus & 14 & 38 & $11.51^{* * *}$ \\
\hline Juncus effusus & 35 & 24 & 2.06 \\
\hline Lychnis flos-cuculi & 34 & 7 & $19.36^{* * *}$ \\
\hline Sorbus aucuparia & 20 & 6 & $7.95^{* *}$ \\
\hline
\end{tabular}

Table 4. Contribution of various plant species in the total number of contacts taken by moose $\mathrm{A}$ and $\mathrm{B}$ at the beginning and at the end of observation period.

\begin{tabular}{|c|c|c|c|c|c|c|}
\hline \multirow{3}{*}{ Species } & \multicolumn{3}{|c|}{$22-25$ June } & \multicolumn{3}{|c|}{$11-20$ July } \\
\hline & \multicolumn{2}{|c|}{$\mathrm{N}$ contacts } & \multirow[t]{2}{*}{$G$-test } & \multicolumn{2}{|c|}{$\mathrm{N}$ contacts } & \multirow{2}{*}{$G$-test } \\
\hline & A & B & & A & B & \\
\hline Lysimachia vulgaris & 401 & 291 & $17.56^{* * *}$ & 75 & 43 & $8.79^{* *}$ \\
\hline Rubus saxatilis & 43 & 406 & $338.96^{* * *}$ & 11 & 176 & $175.57^{* * *}$ \\
\hline Tilia cordata & 25 & 25 & 0 & 149 & 156 & 0.16 \\
\hline Athyrium filix-femina & 128 & 7 & $132.09^{* * *}$ & 53 & 15 & $22.51^{* * *}$ \\
\hline Stellaria holostea & 80 & 9 & $65.08^{* * *}$ & 12 & 24 & $4.08^{*}$ \\
\hline Vaccinium myrtillus & 2 & 5 & - & 51 & 44 & 0.52 \\
\hline Impatiens noli-tangere & 29 & 12 & $7.27^{* *}$ & 5 & 7 & - \\
\hline Carpinus betulus & 6 & 8 & - & 24 & 14 & 2.66 \\
\hline Juncus effusus & 19 & 16 & 0.26 & 18 & 6 & $6.26^{*}$ \\
\hline Lychnis flos-cuculi & 4 & 30 & $22.50^{* * *}$ & 7 & - & - \\
\hline Sorbus aucuparia & 6 & 14 & 3.29 & 1 & 5 & - \\
\hline
\end{tabular}

the lack of differences in their preference by the two moose did not change during the entire month of observation. In foraging on all other plant species, the differences between the calves decreased, e.g. in the case of Athyrium filix-femina the $G$-value decreased from 128.25 to $18.67\left(G_{0.05}=3.84\right)$. None of the differences became more pronounced.

It was also observed that during the first wanderings to the forest, the calves chose the plants somewhat randomly. Table 5 shows the pattern of foraging by calves on Athyrium filix-femina and Rubus saxatilis. The calves had encountered 
these species previously during the short walks before the observations. Moose A bit the fern several times, whereas moose B bit the wild raspberry. During the following wanderings, each animal began foraging by eating "his" more familiar plant despite the fact that both species of plants were equally available and grew close to each other. It was only after having walked a longer distance that the moose began foraging on other plants, too. That behaviour was observed during the entire month of observations. Large patches of Vaccinium myrtillus grew along the distant section of the walking transect, therefore, the calves found them after several days of wanderings and began to forage on Vaccinium equally intensely. The same was observed in the case of Tilia cordata.

There no indication that the calves followed each other in their foraging behaviour.

Table 5. Number of contacts with Athyrium filix-femina and Rubus saxatilis by two moose calves (A and B) in $22-25$ June.

\begin{tabular}{llrr}
\hline \multirow{2}{*}{ Date } & \multicolumn{1}{c}{ Species } & \multicolumn{2}{c}{ N contacts } \\
& & A & B \\
\hline \multirow{2}{*}{ 22 June } & Athyrium filix-femina & 26 & 6 \\
& Rubus saxatilis & 33 & 16 \\
23 June & Athyrium filix-femina & 55 & 1 \\
& Rubus saxatilis & 9 & 170 \\
\multirow{3}{*}{ 24 June } & Athyrium filix-femina & 28 & 0 \\
& Rubus saxatilis & 1 & 67 \\
& Athyrium filix-femina & 19 & 2 \\
& Rubus saxatilis & 0 & 8 \\
\hline
\end{tabular}

\section{Other behaviours of moose calves}

E a t i n g d i r t. It was a deliberate behaviour; the calf approach a fallen tree and ate the soil stuck amongst its roots. This behaviour was observed during all wanderings from the first day of observations to the 6th of July. During the 2 - 3-h walk the moose ate dirt from 1 to 13 times.

D r i n k i n g u ri n e. During the entire observation period, I noted that occasionally a calf approached its urinating brother, put the head under his belly and drank the urine.

$\mathrm{D} r$ in king w a t e r. During the wanderings the calves drank water from the puddles and forest ponds.

Play ing and bath ing. These behaviours were the stable component of calves' wanderings through the forest. They always played in the water. First, they flung their legs in water, then jumped, tried to kick each other with the front 
and hind legs, pranced, and chased each other. The calves regularly bathed, lying in water and wallowing. The eagerness for play was the evidence that the development and growth of calves was good and the hand-rearing ensured their comfort.

$\mathrm{S}$ o $\mathrm{c}$ i a $\mathrm{l}$ b e h a vi o u r s. Since the beginning of hand-rearing, the calves showed strong bonds with each other. They always walked together and the loss of visual contact made them uneasy; they called and searched for each other. Strong bonds also developed between the calves and the author. Moose B (weaker and smaller than his brother) showed the most aggressive and dominant behaviour.

\section{Discussion}

Species composition of plants eaten by moose calves in the Białowieża Primeval Forest did not significantly differed from that found in the food of adult individuals. During the season of leafy vegetation season, the diet of free-living adult moose was dominated by the leaves and twigs of trees and shrubs (58\%), particularly Salix sp., Betula pubescens, Populus tremula, Frangula alnus, Sorbus aucuparia, and Rubus sp. Herbaceous plants composed about $35 \%$ of the diet. They were represented by Lysimachia vulgaris, Vicia sp., Juncus effusus, various species of grasses and sedges, and water plants (Homolka 1989). Dzięciołowski (1974) reported that during the vegetation growth season, moose preferred Vaccinium vitis-idaea, V. myrtillus, Ledum palustre, Alnus glutinosa, Carpinus betulus, and Rubus idaeus. All species of trees eaten by moose calves in the BNP could be found among those listed by Dzięciołowski (1974).

The questions of individual variation in the food choice by moose was studied by Dzięciołowski (1974). Four hand-reared moose were tested with respect to their foraging on provided twigs of various shrubs and trees. Dzięciołowski (1974) found significant quantitative (but not qualitative) differences between the four moose. The group of plants preferred by any one calf included from 1 to 7 species. Vaccinium vitis-idaea was the only plant preferred by all tested moose. Malus silvestris and Vaccinium myrtillus was preferred by three moose, Salix cinerea and $S$. caprea by two moose, and Rubus idaeus by one moose. There were also individual differences in the groups of plants reluctantly eaten by moose. Oxycoccus quadripetalus, Evonymus verrucosa, and Fraxinus excelsior were unwillingly eaten by all moose, whereas Ribes nigrum, Tilia cordata and Juniperus communis - by two moose.

Dzięciołowski (1974) began his tests when the moose were 2 months old, and ended them when they were 17 months old. Unfortunately, the author analyzed the pooled data, therefore, it is not clear whether the differences in food preferences of particular moose were similar during the first and the second spring and summer. 
It is also interesting to compare the foraging behaviour of moose calves with the behaviour of another cervid, the roe deer. I have studied the development of foraging behaviour of roe deer fawns during their first 3 months of life (Kossak 1981b). The methods and study area were similar to those described in this paper (see Kossak 1981a).

The most typical feature of the foraging behaviour of fawns was their very early foraging on plants (ábout 5 days after birth) and steady increase of the number of contacts, plant species taken, and amount of plants eaten. The preferences of fawns toward various plants changed with time following the pattern: lack of interest in a given plant species - attempts of eating - consumption (during a long period of time) or temporary disinterest in the plant species (for short or long time).

In contrast to the roe deer, the attitude of moose towards potential forage species, did not change in time. Moose begin to feed on vegetation later than do the roe deer fawns. The moose diet did not gradually enrich in species, and attempts to eat new plants were not noted. It suggests that in moose the physiological readiness to exploit the various vegetation forage appears concurrently with their first attempts to bite plants. Maybe it is synchronized with the seasonal development of plants.

Both moose and roe deer young consumed dirt and sand during their first weeks of life. This behaviour activates the alimentary canal and introduces the microorganisms enabling the digestion (Bubenik 1965, Espmark 1969, Kossak 1981a).

The moose calves showed individual preferences in quantities of forage plants, whereas in roe deer fawns such preferences were not observed.

The differences in foraging behaviour in moose calves and roe deer fawns can be explained by the differences in their social behaviour. Fawns first begin to eat plants where they are still separated from their mother and siblings (Kurt 1968, Espmark 1969), therefore their behaviour is based on instinct and learning, and not on following other deer. Moose calves are born with much less physical ability, their growth is slower and they begin to eat plants later. The strong mother-calf bond developes soon after the calf is born. Leptich and Gilbert (1989) found that female moose chose softwood and cut-over as their summer habitats (cut-over stands were harvested 16 years earlier and were characterized by abundant forage resulting from regenerating trees and shrubs), whereas males preferred mixed woods and hardwood. The choice of habitat by pregnant females detemines the forage type that the calves will encounter. Calves attend their mothers and this promotes their consumption of those plants, which their mother feeds upon.

Some random choice of food noted in the studied calves and the quantitative differences in their foraging preferences suggest that in the development of moose foraging behaviour, following of the mother is an important factor. However, to explain the role of mother in the development of foraging behaviour of moose calves, it would be necessary to study and compare the food preferences of various family groups. 


\section{References}

Bubenik A. B. 1965. Beitrag zur Geburtskunde und zu den Mutter-Kind-Beziehungen des Reh (Capreolus capreolus L.) und Rotwildes (Cervus elaphus L.). Z. Säugetierk. 30: 65 - 128.

Crossley A. and Gilbert J. R. 1983. Home range and habitat use of female moose in northern Maine a preliminary look. Proc. Northeast Wildl. Conf. 39: 67 - 75 .

Dunn F. 1976. Behavioral study of moose. Maine Dep. Inland Fish and Wildl. Proj. W-66-R-6, Job 2-1: $1-39$.

Dzięciołowski R. 1974. Selection of browse twigs by moose. Acta theriol. 19: $273-281$.

Espmark Y. 1969. Mother-young relations and development of behaviour in roe deer (Capreolus capreolus L.). Viltrevy 6: $461-540$.

Hofmann R. R. 1978. Die Stellung der europäischen Wildwiederkäuer im System der Äsungstypen. [In: Wildbiologische Informationen für den Jäger. R. R. Hofmann, ed.]. Jagd + Hege Verlag, 1: 9 18. St. Gallen.

Homolka M. 1989. Dietary analyses in the European elk (Alces alces) with a view to its prospects in southern Bohemia. Folia zool. 38: 21 - 29.

Kossak S. 1981 a. Hand-rearing and care of a group of roe deer. Acta theriol. 26: $207-218$.

Kossak S. 1981 b. Development of food habits in roe deer. Acta theriol. 26: 483 - 494.

Kurt F. 1968. Socialverhalten des Rehes (Capreolus capreolus L.). Verlag Paul Parey, Hamburg und Berlin: $1-102$.

Leptich D. J. and Gilbert J. R. 1989. Summer home range and habitat use by moose in northern Maine. J. Wildl. Manage. 53: $880-885$.

Renecker L. A. and Hudson R. J. 1989. Seasonal activity budgets of moose in aspen-dominated boreal forests. J. Wildl. Manage. 53: 296 - 302.

Sokal R. R. and Rohlf F. J. 1981. Biometry. 2nd ed. H. W. Freeman and Co. 1-859.

Received 28 May 1991, revised 26 February 1992, accepted 2 March 1992. 